\title{
Improving Vocabulary of Soepraoen Health Academy Student Throught Multimedia in the Classroom
}

\author{
Indrawati Pusparini \\ Program Studi Pendidikan Bahasa Inggris IKIP Budi Utomo Malang \\ Jalan Citandui 46 Malang \\ puspaindra71@gmail.com
}

\begin{abstract}
Abstrak: Sejak pembelajaran kosa kata bagi mahasiswa berperan penting dalam pembelajaran bahasa Inggris, para dosen dituntut agar dapat menggunakan metode dan media yang tepat. Salah satu media yang penting adalah computer yang dapat memberikan dan menyediakan banyak informasi yang diberikan internet. Mahasiswa perlu belajar kosakata tidak hanya menghafalnya tetapi juga dapat belajar sesuai dengan konteks. Komputer memberikan pembelajaran visual yang mahasiswa perlukan agar dapat menerima mata kuliah yang diajarkan dengan cara yang berbeda. Dalam artikel ini, penulis ingin membahas fungsi aplikasi multimedia, khususnya internet sebagai bagian dari media teknologi terkini yang dapat menarik mahasiswa belajar dan mengembangkan kosa kata dalam bahasa Inggris. Penggabungan teknologi yang modern sangatlah penting guna menopang proses pembelajaran di kelas. Teknologi berbasis informasi ini terdiri dari video, gambar, game, grafik, audio, dan lain-lain untuk mendukung kosa kata mahasiswa sehingga mereka dapat mengembangkan kosa katanya dengan lebih mudah di kelas.
\end{abstract}

Kata kunci: komputer, internet, kosa kata, bahasa Inggris, pembelajaran

Soepraoen Health Academy is known as one of the qualified health academy which provide many competent student who are able to compete with not only domestic competitors but also foreign competitors. Therefore, the students are expected to be able to develop their language competent. Vocabulary is one of the important language skill that should be possessed to support their practicing in speaking, listening, reading and writing. Student need to learn vocabulary not only by memorizing but also learning in context. Computer as a multimedia aplication, especially internet as part of modern technology media which can be an interesting way to attract the student learning vocabulary and improve it. Combining such kind of sophitiscated technology is very essensial to support teaching and learning process . It is widely known that technology in education plays an important role in improving the educational skills and knowledge of the people. This is very important especially those who need improve their knowledge in order for them to achieve a successful life in the future. Technology in education is manifested through the use of computers. This is also a great help for teachers since they can already enhance their teaching skills and strategies every time they are facing their class. This technology is very essential for both the students and the teacher. Nowadays, student can access any information, such as: news, games, material, etc much easier from internet than from the book. They can access anytime and everywhere about many informations which they need it.Thus, the use computer especially internet as a part of media in teaching learning process can be an essesial way to attract and improve student's vocabulary.

\section{THE ADVANTAGES AND DISADVANTAG- ES OF TECHNOLOGY IN EDUCATION}

Technology in education plays an important role in the study habits and skills of the student. But, As a teacher, we need to make sure that we are going to be very careful in allowing them to use their computer and surf the internet for them to avoid discovering things that are not part of their studies. It is always important to let them used some of these technology in education as often as it is in order to prevent forgetting the basic way of studying. Here are some advantages and disadvantages from technology in education. 
110 | Indrawati Pusparini, Improving Vocabulary of Soepraoen Health Academy Student ...

\section{Advantages}

Promotes independent learning for the students

Students can already learn from their own even without the assistance of their parents and teachers. They are just going to surf the internet in order to look for the lessons they need to study. Quick accessibility and well-equipped with the skills and knowledge in operating a computer would be very helpful for the students.

\section{Easiear Aceess to information}

The need for heavy books to be brought back and forth from school and home is no longer needed with technology. The books can stay in the classroom because the information that they need is easily accessed on a computer.

\section{Promotes exciting way to educate students}

Since there are lots of images, videos and other graphics and text that may be found in your computer, more students would feel the excitement in studying through the use of the gadget. This is very important in order to arouse their interest in studying.

\section{Disadvantages}

Laziness in studying

Computers make is so easy to find answers that students barely have to look for them. This may result in them having poor study habits and developing a lazy attitude toward their education.

\section{Forgetting the basic way of stuying}

They would no longer rely on the books that are lent by their teachers for them to study since they are already interested to study using the computer. Even simple problems and homework that they need to answer, they are more of seeking the assistance of computers already.

\section{Discovering unsual things in the computer}

Allowing the students to surf the internet doesn't necessarily mean that all the things that they are going to discover are good for their mind and studies. There are several things that are found in the internet which are not good for the students hence they need to be properly guided by their teachers and parents every time they are going to use the computer.

\section{THE IMPORTANCES OF VOCABULARY}

As we know, vocabulary was for long an overlooked aspect of learning a new language. During the last decades, however, the vocabulary has moved from the side into a central position. We find this attention truly well-deserved, as we are confident that vocabulary, including not just words but also their meaning, context and conjugation, is in the very essence of the process of learning a new language. Here are three key reasons why increasing your vocabulary is worth to effort:

\section{Vocabulary is the key to communication}

For a large majority of learners, the ultimate goal of studying is to be able to communicate in a new language. If you do not wish to learn completely on non-verbal skills, mastering vocabulary is not just important, but crucial in a foreign language environment.There is a reason we tend to travel with a dictionary, not a grammar book.

Strong vocabulary allows you to develop other skills

Vocabulary is fundamental but what about the other dimensions? Should we pay any attention to all the other aspects of language learning? Of course we should. The good news is that improving your vocabulary has a direct, positive impact on your capacity to build up your language proficiency as a whole. A leading linguist researcher Paul Nation notes: "Vocabulary is not an end in itself. A rich vocabulary makes the skills of listening, speaking, reading, and writing easier to perform." All in all, instead of contrasting vocabulary with the rest of the language skills, it would be more useful to consider it as solid bedrock upon which to build the overall language proficiency.

The more words you know, the more you will learn

Vocabulary is learned through focused, conscious study, but even more commonly in an indirect manner through listening and reading, using context clues to figure out the meaning. However, this kind of incidental learning is only possible if the amount of unknown words remains low . That is, you must have a significant vocabulary to be able to learn new words from the context in which they appear. This obviously constitutes a clear disadvantage for learners with 
less vocabulary, but also means that "learners who know more words are able to use those known words to learn even more".

\section{MULTIMEDIA APLICATION AS A MEDIA}

Many media application of multimedia can be used in teaching vocabulary both online and offline, such as : (www.manythings.org/ vocabulary) and (www.superteachertools.com) . Teacher also can combine and modify based on the purpose and objective of the English lesson taught.

Here are some multimedia program that can improve the student's vocabulary:

1. Click the letter in the correct order

This game is from www.manythings.org/ vocabulary which can be played online that try to get many vocabularies before the time run out . There are 30 choices for practicing vocabulary, such as : adjective, adverb, animal, home, etc

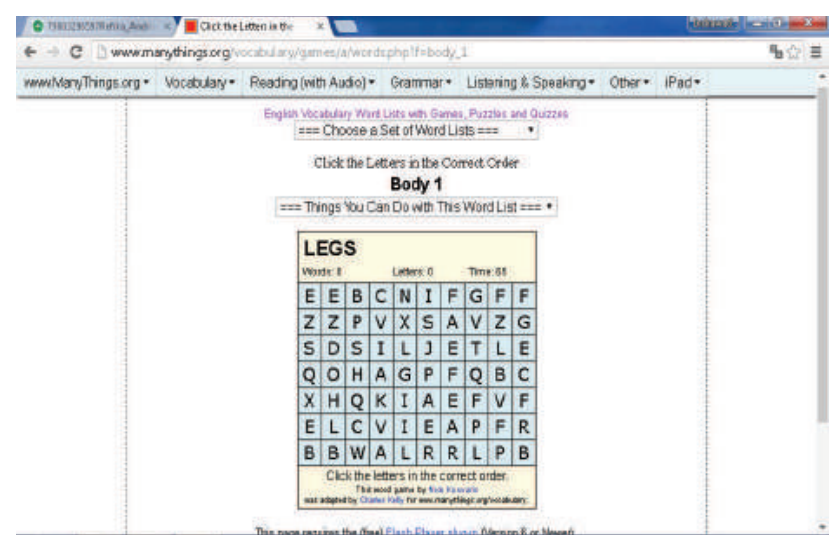

2. Flash hangman game

This game is from www.manythings.org/ vocabulary which can be played online that Try to guess the mystery word before the guesses run out. There are 30 choices for practicing vocabulary, such as : adjective, adverb, animal, home, etc

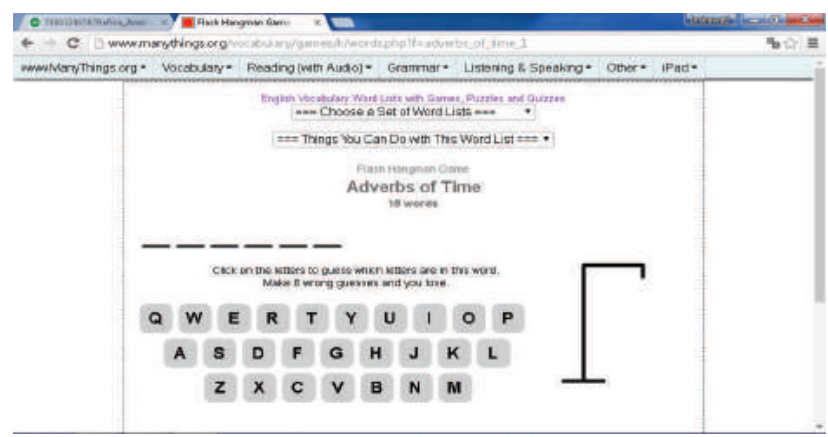

3. Missing consonant game

This game is from www.manythings.org/ vocabulary which can be played online that See a word without the consonants, guess what the word is, then see the answer. The consonants have been removed from these words. The students try to guess what each word is, then click the answer button to see the answer. Each time playing, the game will be loaded by 15 words randomly chosen from the 52 word vocabulary list and then shuffled. There are 30 choices for practicing vocabulary, such as : adjective, adverb, animal, home, etc

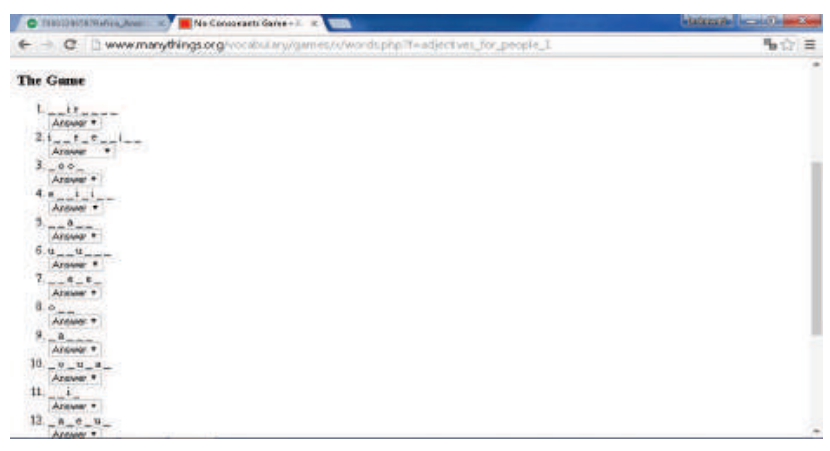

4. Word search puzzle

This kind of game is sometimes called "Word Find" or "Hidden Words." This game is from www.manythings.org/vocabulary which can be played online that try to get many vocabularies before we play to the next level . There are 30 choices for practicing vocabulary, such as : adjective, adverb, animal, home, etc. the format may challenge the students think deeply, creative and have fun in learning vocabulary.

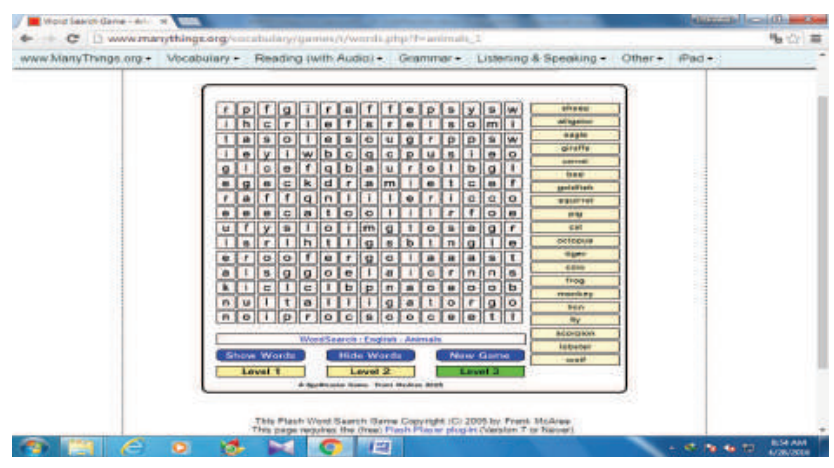

5. Jeopardy

Jeopardy gameis one of the gameapplications from www.superteachertools.com which can be played online or offline. The teacher 
112 | Indrawati Pusparini, Improving Vocabulary of Soepraoen Health Academy Student ...

can make 25 questions that will be shown from the subjects (sample game): states and capitals, government, U.S History, History, Geography, or the teacher can arrange the questions based on the class need. It would be interesting because there are some sound effects.

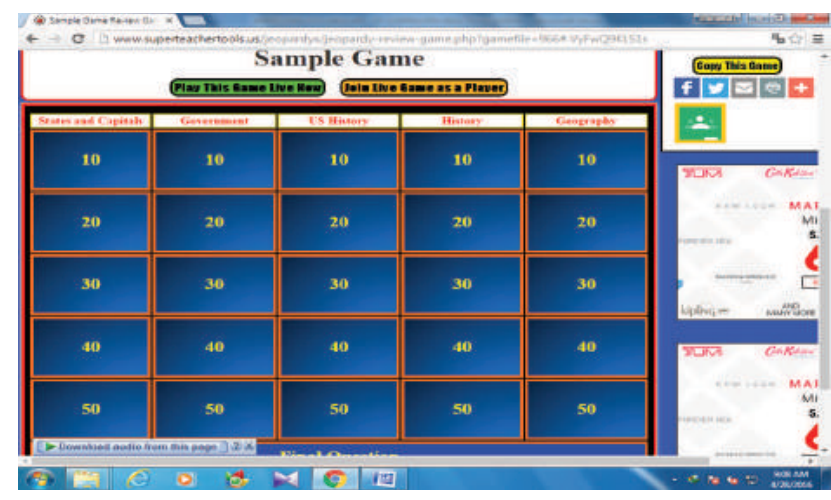

6. Who wants to be a millionaire

Who wants to be a millionaire game is an application that force the teacher to create an interesting materials through game. Sometime, the teacher can create the real game as ever performed in television. When the students can answer one question correctly means they can go to the next level until they reach one millionaire.

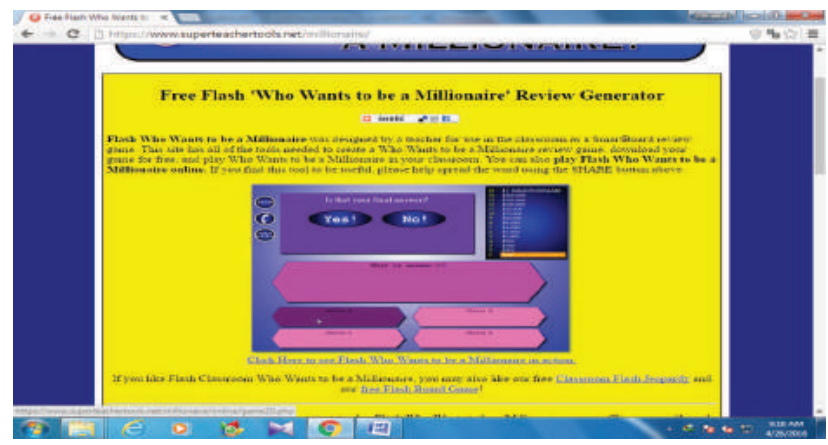

\section{CONCLUSION}

From the description of several multimedia application games above show that the multimedia application games will give much benefit for the students. The benefit such as :

1. Improving the student's vocabulary knowledge

The existing multimedia games, include the picture as well as the sound effect enable the students learn the vocabulary deeply. They will get better understanding by helping of the visual images.

2. Motivation students learning

Learning something differently can create new atmosphere in which the student will have fun. So, the anxiety of the student will low and learning joyfully.

3. Building cooperative learning

Student will share and gain new knowledge, sometimes need to cooperate in group suppose to be the best participant in game.

4. Interactive learning

Interactive learning between the learner, the learning system, and the learning material. Numerous studies have found that interactivity has a strong positive effect on learning . learners can learn faster, and have better attitudes toward learning when using interactive multimedia.

Multimedia is becoming an acceptable medium in education in teaching and learning process, especially learning vocabulary. Multimedia is an interactive and integrated media because it contains many format such as video, picture, sound effect, graphic, etc. so, the variety of teaching vocabulary can be presented by many games or other multimedia applications. Teaching and learning vocabulary use multimedia in Soepraoen Academic give benefit not only for the students but also for the teacher. The teacher can create their own material by duplication of the games based own the class need. This is also the effective way to improve he Soepraoen Health Academic.

\section{REFERENCES}

Arikunto, S. 2002. Metodologi Penelitian. Penerbit PT. Rineka Cipta. Jakarta

Borg, R.W., \& Gall. M.D. 1983. Educational Research: An Introduction (4 ${ }^{\text {th }}$ ed.). New York and London: Longman Inc.

Finnochiaro, M.(1974). English as a Second Language: from Theory to Practice,

London:Regents Publishing Company, In Harris, David P. (1974) Testing English as a Second Language, New York: Macmilland Publishing co 